\title{
OPTIMAL METHODS OF ANTIGEN RETRIEVAL FOR ORGANIC ANION TRANSPORTERS IN CRYOSECTIONS OF THE RAT KIDNEY
}

\author{
Hrvoje BRZICA ${ }^{1}$, Davorka BRELJAK ${ }^{1}$, Marija LJUBOJEVIĆ ${ }^{1}$, Daniela BALEN ${ }^{1}$, \\ Vedran MICEK ${ }^{1}$, Naohiko ANZAI ${ }^{2}$, and Ivan SABOLIĆ ${ }^{1}$ \\ Institute for Medical Research and Occupational Health, Zagreb, Croatia ${ }^{1}$, \\ and Pharmacology and Toxicology, Kyorin University School of Medicine, Tokyo, Japan ${ }^{2}$
}

\begin{abstract}
To localise antigens by immunocytochemistry (IC), the samples of tissues or cells are usually denatured by fixation, and either frozen and cryosectioned, or embedded in paraffin before sectioning. p-Formaldehyde (PFA; formalin) is a common fixative, which preserves antigenicity of proteins, but damages the tissue/cell morphology and "masks" the antibody binding sites (epitopes). In order to "unmask" epitopes, some kind of antigen retrieval (AR) is used. The aim of this study was: a) to find an optimal AR method in cryosections of in vivo PFA-fixed kidneys for organic anion transporters (Oat) that reside in the basolateral (Oat1, Oat3) and brush-border membrane (Oat2, Oat5) of the rat renal proximal tubules, and b) using optimal method, to compare IC staining of Oats in kidneys that had been PFA-fixed in vivo or in vitro. IC staining in untreated cryosections was compared with that following detergent treatment or microwave heating in citrate buffer of $\mathrm{pH} 3, \mathrm{pH} 6$, or $\mathrm{pH} \mathrm{8}$, with or without alcohol pre-treatment. The preferred AR method for Oat1, Oat2, and Oat5 was heating of cryosections at $\mathrm{pH} 6$, and for Oat3 heating at $\mathrm{pH} 3$, without alcohol pre-treatment. Compared with tissue fixed in vivo, tissue fixed in vitro exhibited damaged tubule morphology, similar staining intensity of Oat1 and Oat3, and higher staining intensity of Oat2 and Oat5. We conclude that for optimal IC presentation, each Oat in the rat kidney has to be treated individually, with different fixation and AR approach.
\end{abstract}

KEY WORDS: cell membrane, cryosections, immunocytochemistry, immunofluorescence, membrane transporters, proximal tubule

Immunocytochemistry is a method for determining the exact site of individual proteins in tissues and cells. Tissues/cells for immunocytochemistry are often denatured by fixation with (2 to 10) $\% p$-formaldehyde (PFA, formalin). However, fixation with PFA has some drawbacks; it "masks" the antibody binding sites (epitopes) on some antigens, and alters cellular morphology by damaging the cell structure (1). It is not clear how PFA reacts with proteins, except that it cross-links reactive sites within the same proteins and between adjacent proteins via methylene bridges (2). However, not all proteins are masked by PFA at the same rate and intensity. For instance, monoclonal antibodies fail to label neuro-filaments after one day, lymphocyte antigens LN1, LN2, and LN3 have shown reduced staining after three days, while carcinoembryonic antigen stains even after 14 days of tissue fixation in formalin (3). This problem is more evident for monoclonal then polyclonal antibodies, because polyclonal antibodies can bind to more reactive places on proteins (2). In order to "unmask" cryptic epitopes, one has to apply a series of antigen retrieval techniques for each set of antigen/antibody separately in order to find optimal conditions for the immunocytochemical presentation of an antigen. Antigen retrieval is defined as "a high-temperature heating method to recover antigenicity of tissue sections that have been masked by formalin fixation" (4). Most of the previous 
studies of antigen retrieval methods were performed with sections of paraffin-embedded tissues/cells. Depending on the antibodies used, these methods include treatment with various alcohols (to remove paraffin), different heating temperatures, pressures, osmolality, and chemical composition of the reagents, $\mathrm{pH}$, and different timing of treatments (5-10). The $\mathrm{pH}$ of reagents seems to play a crucial role in antigen retrieval; $\mathrm{pH} 8$ to $\mathrm{pH} 9$ has been proposed as optimal for starting with a new antigen (9). However, this is not true for all antigens; the optimal condition for labelling thrombospondin in paraffin-embedded sections was antigen retrieval in an acidic buffer (pH 1) (11).

The revealing methods have been less used with cryosections of PFA-fixed tissues, organs, or cells. While some antibodies weakly recognised, or failed to recognise their epitopes in PFA-fixed tissue cryosections, they did it after treatment with a detergent such as sodium dodecyl sulfate (SDS), which is more commonly used in gel electrophoresis. Thus, SDS treatment of cryosections enhanced the immunostaining of $\mathrm{Na} / \mathrm{K}$-ATPase and vacuolar $\mathrm{H}^{+}$ATPase (56 kDa subunit) in various tubules, but this was the only way to stain caveolin in endothelial cells, as well as the anion exchanger AE2 in the principal cells and $\mathrm{Na} / \mathrm{K}$-ATPase in intercalated cells of the collecting duct in rat kidney $(1,12-14)$. However, the same treatment of cryosections did not affect the staining of megalin and water channels AQP1 and AQP2 (12). These findings have indicated a need for an individual approach to each antigen and its antibody, and for defining an optimal antigen retrieval method and conditions for each protein before its detailed characterisation by immunocytochemistry in tested tissues/cells.

Using cryosections of rat kidneys PFA-fixed in vivo, we $(15,16)$ and others (17-19) have recently established a detailed distribution of several organic anion transporters (Oats) localized to the basolateral (BLM) (Oat1, Oat3) and brush-border membrane (BBM) (Oat2) of mainly proximal tubules (PT) in the rat nephron. The highest expression of the Oat1 protein was observed in the PT S2 segments in the cortex, where it exhibited male (M)-dominant sex differences, whereas the Oat3 protein was localised basolaterally in various nephron segments, being the strongest and M-dominant in the cortical tubules (15). The Oat2 protein was strongly expressed in the BBM of PT S3 segments, even more so in females (16). However, in these studies the conditions for optimal immunocytochemical presentation of Oats have been only superficially tested, and a detailed study of antigen retrieval has not yet been performed. In addition, we have included another transporter in the BBM of PT $\mathrm{S} 3$ segments with $\mathrm{F}$-dominant expression, that is, Oat5 (20), whose distribution along the rat nephron has yet to be described in detail. With these experiments we aim to find an optimal method and conditions for retrieving cryptic antigens, possible non-specific staining, and artifacts. After establishing optimal antigen retrieval conditions, we aim to compare the pattern of localisation and staining intensity of all 4 Oats in cryosections of rat kidneys fixed with PFA in vivo and in vitro in order to test these two modes of fixation for the integrity of tubule morphology and immunostaining efficiency.

\section{MATERIAL AND METHODS}

\section{Animals and treatment}

The experiments included adult, three-month-old male and female Wistar rats from the breeding colony of the Institute for Medical Research and Occupational Health, Zagreb. Due to significant sex differences in the expression of individual Oats in the rat kidney (15, $16,20)$, male rats were used to study Oat1 and Oat3, whereas female rats were used to study Oat 2 and Oat5. The animals were bred and maintained according to the Guide for Care and Use of Laboratory Animals (National Institute of Health, Bethesda, USA, 1996). The experiments were approbed by the Institute's Ethics Committee.

\section{Antibodies and chemicals}

Polyclonal antibodies against Oat1 (Slc22a6), Oat2 (Slc22a7), Oat3 (Slc22a8), and Oat5 (Slc22a19) were raised in rabbits; their use was described in our previous reports $(15,16,20)$. The secondary antibody was CY3-labelled goat anti-rabbit IgG (GARCY3), which was purchased from Jackson ImmunoResearch (West Grove, PA, USA).

Anaesthetics (Narketan and Xylapan) were purchased from Chassot AG (Bern, Switzerland). Other chemicals used were of the highest purity available and purchased from Sigma (St. Louis, MO, USA) or Fisher Scientific (New Jersey, NY, USA).

\section{Tissue fixation and immunocytochemistry}

Rats were sacrificed either by decapitation or were anaesthetised (Narketan, $80 \mathrm{mg} \mathrm{kg}^{-1}$ b.m. + Xylapan, 
$12 \mathrm{mg} \mathrm{kg}^{-1}$ b.m., i.p.), and their circulatory system was perfused via the left ventricle of the heart in vivo using the Masterflex pump (Cole-Parmer, Chicago, IL, USA), first with aerated $\left(95 \% \mathrm{O}_{2}+5 \% \mathrm{CO}_{2}\right)$ and temperature-equilibrated $\left(3{ }^{\circ} \mathrm{C}\right)$ phosphate-buffered saline (PBS; $137 \mathrm{mmol} \mathrm{L}^{-1} \mathrm{NaCl}, 2.7 \mathrm{mmol} \mathrm{L}^{-1} \mathrm{KCl}$, $8 \mathrm{mmol} \mathrm{L}-1 \mathrm{Na}_{2} \mathrm{HPO}_{4}, 2 \mathrm{mmol} \mathrm{L}^{-1} \mathrm{~K}_{2} \mathrm{PO}_{4}, \mathrm{pH}$ 7.4) for $\sim 2$ min (to remove blood via the incisioned abdominal vena cava) and then with a $100 \mathrm{~mL}$ fixative $(4 \%$ PFA in PBS) for $\sim 5$ min. The kidneys from nonperfused and in vivo perfused animals were removed, decapsulated, cut in $\sim 1 \mathrm{~mm}$ thick sagittal slices, and the slices were further kept in the same fixative for $24 \mathrm{~h}$ at $4{ }^{\circ} \mathrm{C}$, followed by extensive washing in PBS, and stored in PBS containing $0.02 \% \mathrm{NaN}_{3}$ at $4{ }^{\circ} \mathrm{C}$ until use.

Before cryosectioning, tissue slices were infiltrated with $30 \%$ sucrose (in PBS) overnight, embedded in OCT-medium (Tissue-Tek, Sakura, Japan), frozen at $-25^{\circ} \mathrm{C}$, and sectioned in a Leica CM 1850 cryostat (Leica instruments GmbH, Nussloch, Germany). Four-micrometer thick cryosections were collected on Superfrost-plus microscope slides, dried at room temperature for $3 \mathrm{~h}$, and stored at $4{ }^{\circ} \mathrm{C}$ until use.

The optimal conditions for immunostaining of individual transporters were tested in cryosections of the kidneys fixed in vivo; the staining of untreated cryosections was compared with that of cryosections processed with the following three antigen retrieval methods before applying the primary antibody: a) SDS treatment, b) microwave heating in citrate buffers of $\mathrm{pH} \mathrm{3,pH} \mathrm{6,} \mathrm{and} \mathrm{pH} 8$, and c) treatment with different alcohols (steps used for deparaffination/delipidation of paraffin-embedded sections), followed by microwave heating in citrate buffers of $\mathrm{pH} 3, \mathrm{pH} 6$, and $\mathrm{pH} 8$. Having established the optimal method and conditions, we compared the staining pattern and intensity for each Oat in the kidneys fixed by perfusion in vivo with that in the non-perfused kidneys, fixed in vitro.

The untreated cryosections were (steps); rehydrated in PBS for $15 \mathrm{~min}$, incubated in BSA ( $1 \%$ bovine serum albumin in PBS) for $30 \mathrm{~min}$ in order to prevent non-specific binding of the antibody, incubated in primary antibody (optimally diluted in PBS) at $4{ }^{\circ} \mathrm{C}$ overnight, rinsed in high-salt PBS (PBS $+1.8 \% \mathrm{NaCl}$; $2 \times 5 \mathrm{~min})$ and normal PBS (2x5 min), incubated in secondary antibody $\left(1.6 \mu \mathrm{g} \mathrm{mL}^{-1}\right.$ in PBS) at room temperature for $1 \mathrm{~h}$, rinsed in high-salt PBS $(2 \times 5 \mathrm{~min})$ and PBS $(2 \times 5 \mathrm{~min})$, overlayed with a flourescensce fading retardant (Vectashield; Vector Laboratories
Inc., Burlingame, CA, USA), covered with the cover glass, and sealed with nail-polish.

The SDS-treated cryosections were (steps): rehydrated in PBS for $15 \mathrm{~min}$, incubated in SDS solution (1\% SDS in PBS) for 5 minutes, rinsed in PBS (4x5 min), blocked with BSA for $30 \mathrm{~min}$, and further processed as described above for untreated cryosections.

The microwave-treated cryosections were (steps): rehydrated in PBS for $15 \mathrm{~min}$, immersed in $10 \mathrm{mmol}$ $\mathrm{L}^{-1}$ citrate buffer ( $\mathrm{pH} 3, \mathrm{pH} 6$, or $\mathrm{pH} 8$ ), and heated in a microwave oven at $800 \mathrm{~W}$ in 4 cycles $(5 \mathrm{~min}$ each), then cooled down to room temperature in the same buffer for $20 \mathrm{~min}$, rinsed in PBS ( $3 \times 5 \mathrm{~min})$, incubated in $0.5 \%$ Triton X-100 in PBS (15 min) and in $2 \%$ Triton X-100 in PBS (30 min), rinsed in PBS (2x5 min), blocked in BSA (30 min), incubated in primary antibody at $4{ }^{\circ} \mathrm{C}$ overnight, rinsed in $0.1 \%$ Triton X-100 in PBS (10 min) and PBS (2x5 min), incubated in secondary antibody at room temperature for $1 \mathrm{~h}$, rinsed in $0.1 \%$ Triton X-100 (10 min) and PBS $(2 \times 5 \mathrm{~min})$, overlayed with a flourescensce fading retardant (Vectashield; Vector Laboratories Inc., Burlingame, CA, USA), and further processed as described above for untreated cryosections.

The alcohol-treated cryosections underwent the following consecutive steps: delipidation in a series of alcohols, including $100 \%$ xylol (30 min), $100 \%$ propanol (5 min), $96 \%$ ethanol ( $5 \mathrm{~min}), 75 \%$ ethanol ( $5 \mathrm{~min}$ ), and $60 \%$ ethanol $(5 \mathrm{~min})$, then rinsing in distilled water (5 min), rehydration in PBS (15 min), followed by the steps listed for microwave-treated cryosections.

Immunostaining was inspected with the Opton III RS fluorescence microscope (Opton Feintechnik, Oberkochen, Germany) using a Spot RT Slider camera and software (Diagnostic Instruments, Sterling Heights, MI, USA). The Oat-related immunostaining, imaged in red fluorescence of $\mathrm{CY} 3$, and the tubule morphology, imaged in green background fluorescence of the tissue, were taken separately using specific cut-off filters with no bleed-through effects. Due to specific sex and zone differences in the tubular expression of various Oats in rat kidneys $(15,16,20)$, the immunostaining of Oat1 and Oat3 was studied in the cortex of male rats, whereas the immunostaining of Oat2 and Oat5 was studied in the outer stripe of female rats. Each set of images, related to the individual Oat, was taken using the same fluorescence-recording parameters. The colour images were then imported into Adobe Photoshop 6.0, assembled in panels, converted into 
black and white mode, and labelled. The data shown represent the findings in cryosections from three rats in each experimental group.

\section{RESULTS}

Optimal antigen retrieval conditions for basolateral transporters Oat1 and Oat3

Oat1

As shown in Figure 1 for the kidneys fixed in vivo, the untreated cryosections exhibited weak staining of Oat1 in the BLM of individual PT in the cortex (A). The SDS-treatment increased the number of weakly positive tubules (B). In the microwave-treated cryosections, the staining intensity depended on buffer $\mathrm{pH}$, and followed the pattern $\mathrm{pH} 3<\mathrm{pH} 6<\mathrm{pH} 8$. However, the use of cryosections at $\mathrm{pH} 8$ was strongly compromised by numerous tubules partially (E, arrows) or completely (data not shown) detached from the microscope slides. In cryosections pre-treated with alcohols and then heated in a microwave (F-H), Oat1 staining in the PT BLM followed the same pattern as in the microwave-treated cryosections, but at much lower level of intensity.

PT morphology was compared with Oat1 staining in the same tubules between tissue cryosections of kidneys fixed in vitro and in vivo that had been microwave-treated at pH 6 (Fig. 2). Whereas the tubule profiles in cryosections of the kidneys fixed in vitro showed collapsed lumina, filled with cellular debris (A), the tubules in cryosections of the kidneys fixed in vivo exhibited regular appearance, with open lumina and sharp contours $(\mathrm{C})$. The staining intensity of Oat1 in the PT BLM was similar in both cases (compare B and D), except that some tubules in the kidneys fixed in vitro exhibited shorter basolateral invaginations (B, arrows).
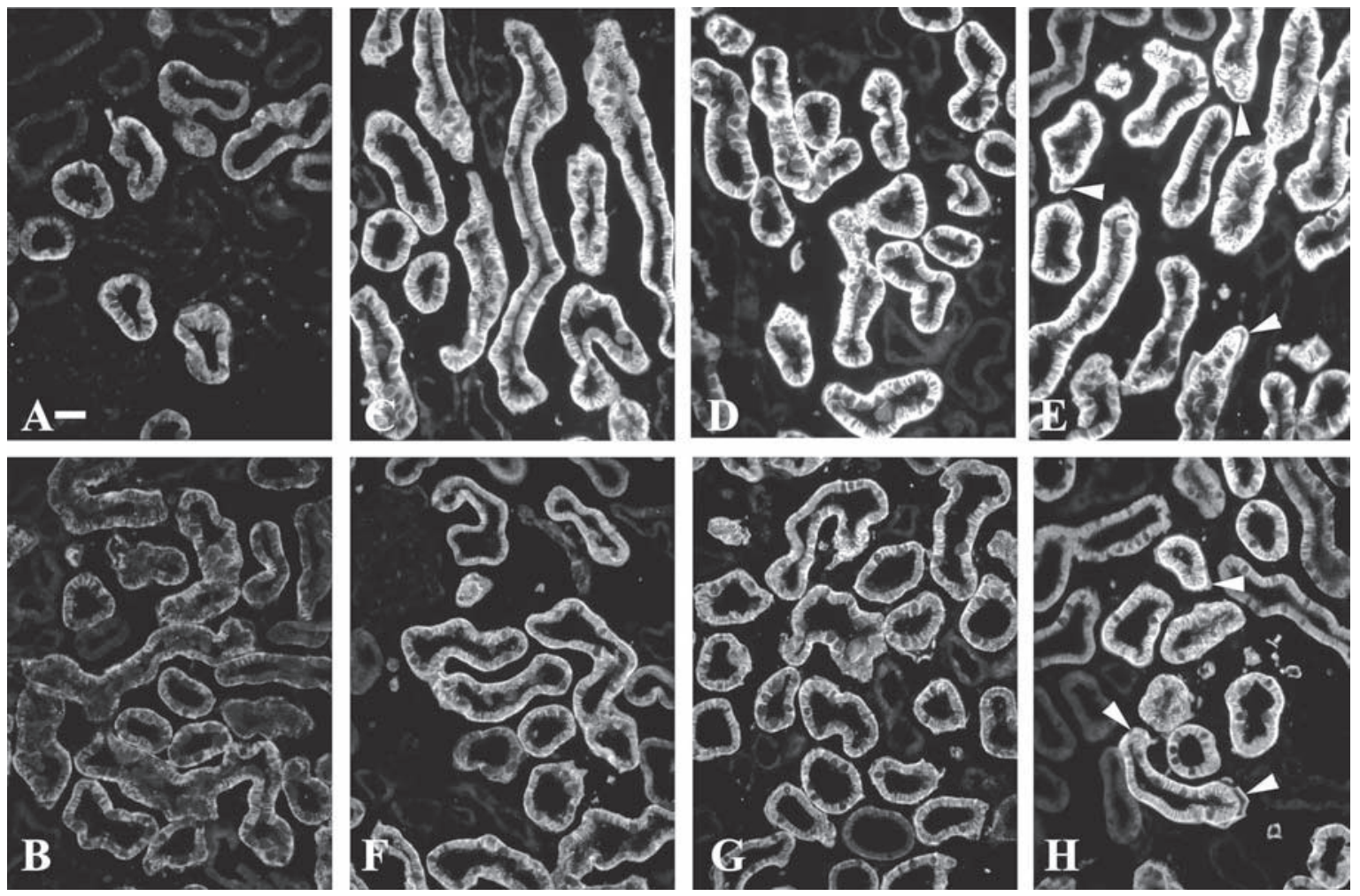

Figure 1 Antigen retrieval conditions for Oat1 in untreated (A), SDS-treated (B), microwave-treated (C-E), and alcoholtreated (F-H) cryosections of the kidneys fixed in vivo. (A) Untreated cryosections show a weak staining of the BLM in individual proximal tubules. (B) SDS-treated cryosections have a higher number of weakly stained tubules. (C-E) Microwave-treated cryosections in citrate buffers of $\mathrm{pH} 3(\mathrm{C}), \mathrm{pH} 6(\mathrm{D})$, and $\mathrm{pH} 8(\mathrm{E})$ exhibit strong BLM staining in the cortical proximal tubules, the strongest being at $\mathrm{pH} 8(E)$. (F-H) In cryosections pre-treated with alcohols, followed by microwave heating in citrate buffer of $p H 3(F), p H 6(G)$, and $p H 8(H)$, the staining intensity of the BLM in the tubules is significantly weaker than in the microwave-treated cryosections. At $\mathrm{pH} 8$, in both microwave-treated $(E)$ and alcohol-treated cryosections $(H)$, many tubules are partially (arrowheads) or completely (not shown) detached from the microscope slide (arrowheads). Scale bar $=20 \mu \mathrm{m}$ 

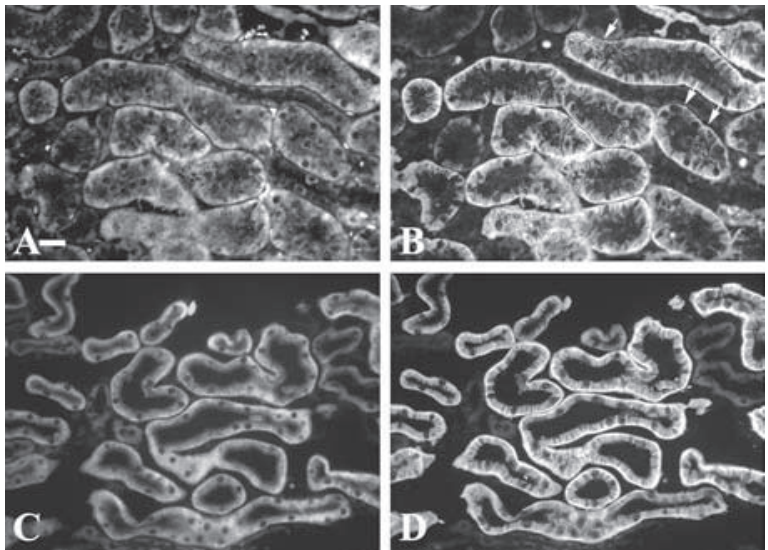

Figure 2 Comparison of proximal tubule morphology $(A, C)$ and Oat1-immunostaining $(B, D)$ in the same tubules between cryosections of the kidneys fixed in vitro ( $A$, $B)$ and in vivo $(C, D)$ that were microwave-treated at pH 6. (A) Proximal tubules in kidneys fixed in vitro show collapsed lumina, filled with cellular debris, whereas (B), Oat1 in the BLM of the same tubules is strongly stained, but some tubules lost the BLM invaginations (arrows). (C) Proximal tubules in cryosections of the kidneys fixed in vivo are open, with sharp borders and regular appearance, and (D), the intensity of Oat1 staining in the BLM of these tubules is strong. Scale bar $=20 \mu \mathrm{m}$


Oat3

Figure 3 shows the data on antigen retrieval for Oat 3 in cryosections of the kidneys fixed in vivo. In untreated sections, Oat3 staining in the BLM of various cortical tubules was weak (A). In the SDStreated cryosections, the specific staining was even weaker, and a high non-specific background staining in all tubule profiles was observed (B). Heating in a microwave showed that Oat3 was best stained in a citrate buffer of $\mathrm{pH} 3$ (C), and less of pH 6 (D) and pH 8 (E). The same pattern, but with lower staining intensity, was observed in cryosections pre-treated with alcohols (F-H).

Figure 4 compares the morphology of cortical tubules and Oat 3 staining in the same tubules between kidneys fixed in vitro and in vivo. In the kidneys fixed in vitro, most cortical tubules had irregular and/or collapsed lumina, filled with cellular debris (A), whereas in cryosections of the kidneys fixed in vivo, the tubules were open, and had a regular appearance with sharply delineated borders $(\mathrm{C})$. The intensity of


Figure 3 Antigen retrieval conditions for Oat3 in untreated (A), SDS-treated (B), microwave-treated (C-E), and alcohol-treated (F-H) cryosections of the cortex of kidneys fixed in vivo. (A) Untreated cryosections show a weak staining of the BLM in various cortical tubules. (B) SDS-treated cryosections exhibit a significant non-specific background staining, and a hardly visible specific staining of the BLM. (C-E) Microwave-treated cryosections in citrate buffers of $p H 3(C)$, pH $6(D)$, and $p H 8(E)$ exhibit significant BLM staining in various cortical tubules, the strongest being at $p H 3(C)$. $(F-H)$ In cryosections pre-treated with alcohols, followed by microwave heating in citrate buffer of $p H 3(F), p H 6$ $(G)$, and $\mathrm{pH} 8(\mathrm{H})$, BLM staining in the cortical tubules exhibits a similar pattern, but weaker intensity than in the microwave-treated cryosections. At pH 8, in both microwave-treated and alcohol-treated cryosections many tubules exhibit signs of detachment from the microscope slide (not shown). Scale bar $=20 \mu \mathrm{m}$ 

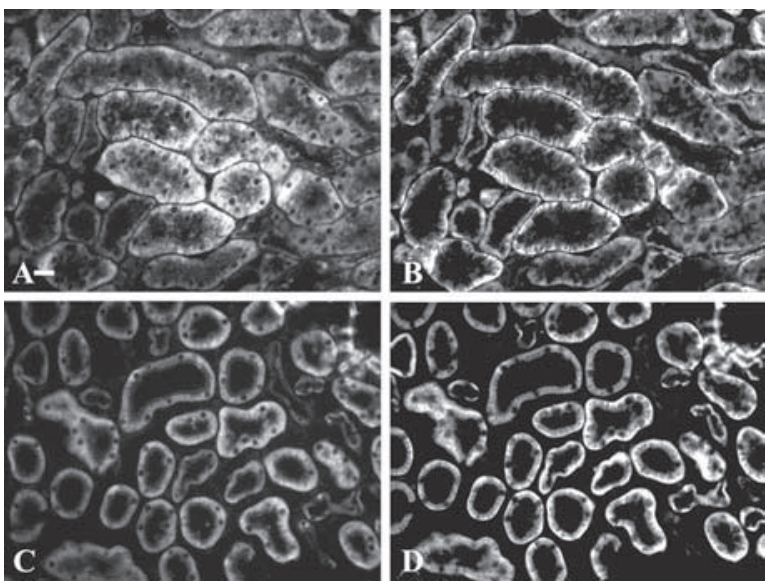

Figure 4 Comparison of PT morphology $(A, C)$ and Oat3immunostaining $(B, D)$ in the same tubules between cryosections of the kidneys fixed in vitro $(A, B)$ and in vivo $(C, D)$ that were microwave-treated at $\mathrm{pH} 3$. (A) Most cortical tubules in the kidneys fixed in vitro have collapsed lumina, filled with cellular debris, whereas (B) Oat3 in the BLM of the same tubules is strongly stained. (C) Various cortical tubule profiles in cryosections of the kidneys fixed in vivo are open, with sharp borders and regular appearance, and (D), the intensity of basolateral Oat3 staining in these tubules is strong. Scale bar $=20 \mu \mathrm{m}$
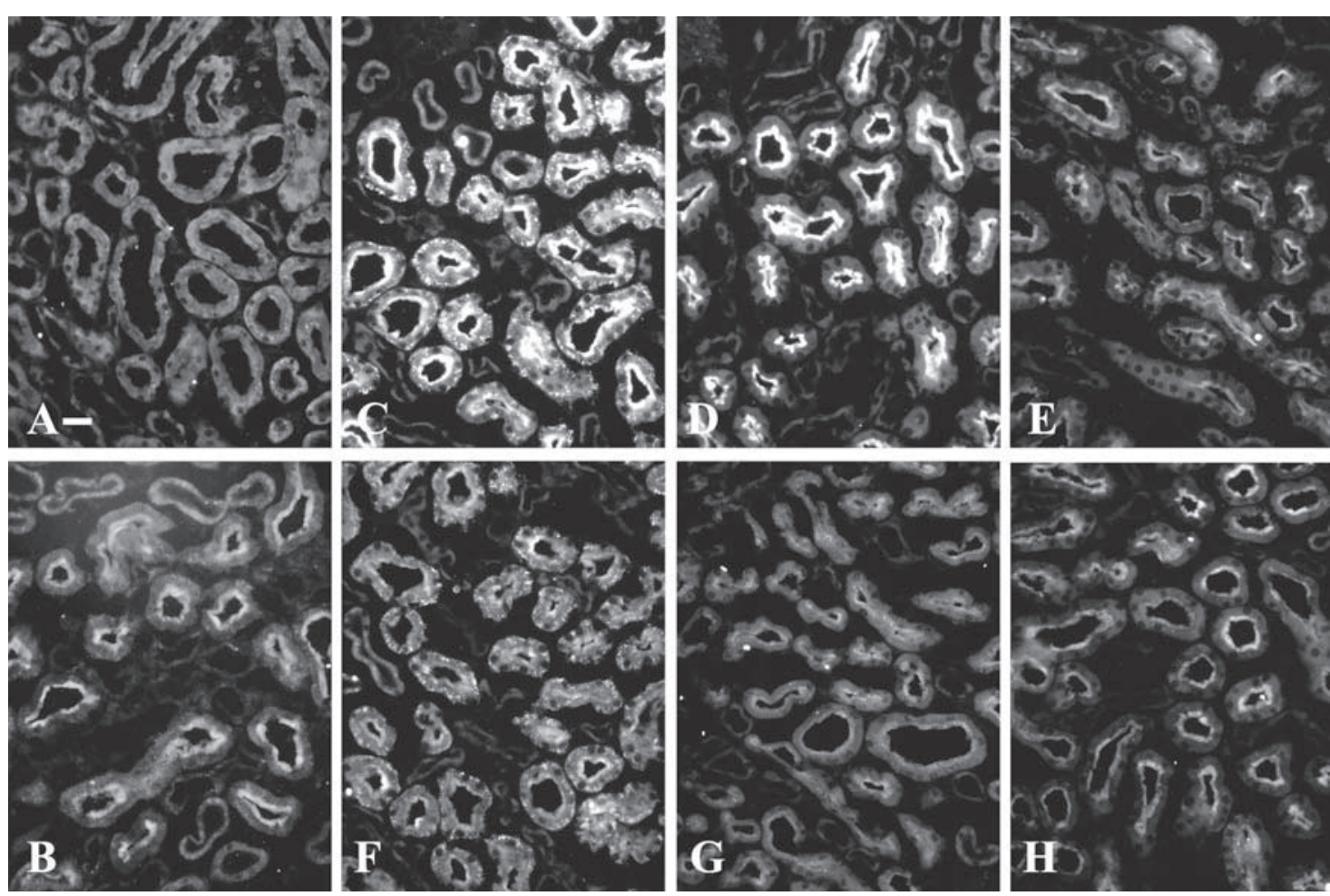



basolateral Oat3 staining in various cortical tubules, however, was similarly strong between the kidneys fixed in vitro (B) and in vivo (D).

Optimal antigen retrieval conditions for brushborder transporters Oat2 and Oat5

\section{Oat2}

Figure 5 shows antigen retrieval for immunostaining Oat2 in cryosections of the kidneys fixed in vivo. In the untreated cryosections (A), no significant staining was observed, whereas in the SDS-treated cryosections (B), Oat2 was weakly stained in the BBM of PT S3 segments in the outer stripe. In the microwave-treated cryosections in citrate buffer of $\mathrm{pH} 3$ (C), we observed a significant non-specific background staining in all S3 segments. In addition, strongly stained were the BBM and non-identified intracellular organelles, mainly localised at the basal cell domain. However, at $\mathrm{pH} 6$ (D), non-specific background staining was much lower, and only the BBM was positive, whereas

Figure 5 Antigen retrieval conditions for Oat2 in untreated (A), SDS-treated (B), microwave-treated (C-E), and alcohol-treated (F-H) cryosections of the outer stripe of kidneys fixed in vivo. (A) Untreated cryosections show no significant staining in the tubules of the outer stripe. (B) SDS-treated cryosections exhibit a weak staining of the BBM in the proximal tubule S3 segments. (C-E) Microwave-treated cryosections in citrate buffers of various $p H$; at $p H 3(C)$ they exhibit a significant background in all tubules and strong staining of the BBM and intracellular organelles in the proximal tubule S3 segments; at pH $6(D)$ a strong staining of the BBM alone; and at pH 8 (E) only a weak staining of the BBM in the S3. (F-H) In cryosections pre-treated with alcohols, followed by microwave heating in citrate buffer of $p H 3$ $(F), p H 6(G)$, and $p H 8(H)$, the staining intensity of the BBM in the proximal tubule $S 3$ segments is much weaker than in the microwave-treated cryosections. Scale bar $=20 \mu \mathrm{m}$ 



Figure 6 Comparison of proximal tubule $S 3$ segment morphology $(A, C)$ and Oat2 immunostaining $(B, D)$ in the same tubules in the outer stripe between cryosections of the kidneys fixed in vitro $(A, B)$ and in vivo $(C, D)$ that were microwave-treated at $p H$ 6. (A) All S3 segments in the kidneys fixed in vitro have collapsed lumina, filled with cellular debris, whereas (B), Oat 2 in the BBM of the same tubules is strongly stained. $(C)$ The proximal tubule $S 3$ segments in cryosections of the kidneys fixed in vivo are open, with sharp borders, and regular appearance, and $(D)$, the intensity of Oat 2 staining in their BBM is much weaker than in cryosections of the kidneys fixed in vitro. Scale bar $=20 \mu \mathrm{m}$
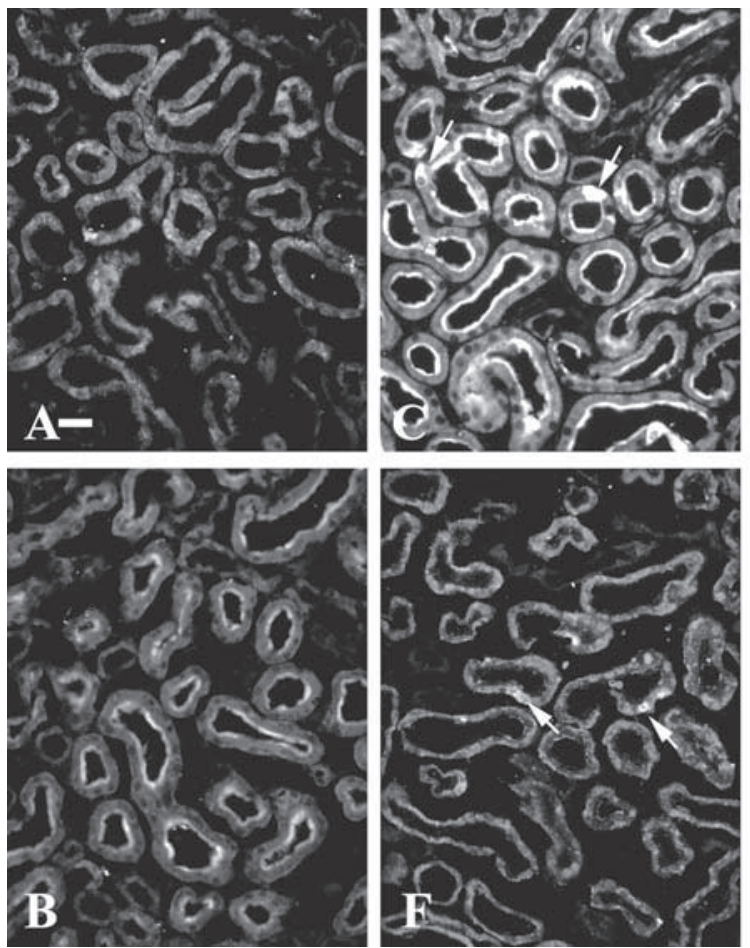

at $\mathrm{pH} 8$ (E) only a weak staining of the BBM was observed. Cryosections pre-treated with alcohols, and microwave heated in citrate buffer, showed much weaker Oat2 staining intensity in the BBM at all $\mathrm{pH}$ values than the microwave only-treated cryosections.

Cryosections treated with microwave at $\mathrm{pH} 6$ were used to compare morphology of the PT S3 segments and Oat2 staining in the same segments between kidneys fixed in vitro and in vivo (Figure 6). In the kidneys fixed in vitro, various tubule profiles had collapsed lumina, filled with cellular debris (A), whereas in the kidneys fixed in vivo, the tubules had regular appearance, with open lumina and sharp borders (C). The intensity of Oat2 staining in the $\mathrm{BBM}$ was stronger in the tubules of the kidneys fixed in vitro (compare $\mathrm{B}$ and $\mathrm{D}$ ).

\section{Oat5}

Figure 7 shows antigen retrieval for immunostaining Oat5 in the tubules of the outer stripe in cryosections of
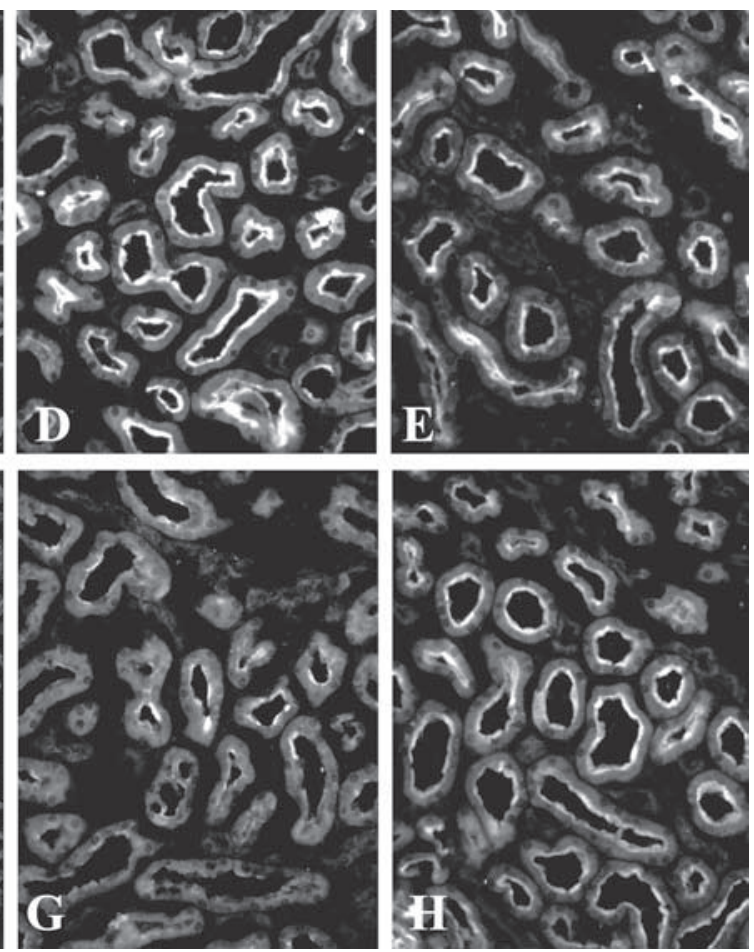

Figure 7 Antigen retrieval conditions for Oat5 in untreated (A), SDS-treated (B), microwave-treated (C-E), and alcohol-treated $(F-H)$ cryosections of the outer stripe of kidneys fixed in vivo. (A) Untreated cryosections show no significant staining in the tubules of the outer stripe. (B) SDS-treated cryosections exhibit a weak staining of the BBM in the proximal tubule S3 segments. (C-E) Microwave-treated cryosections in citrate buffers of various pH exhibit a significant background in all the tubules at $\mathrm{pH} 3(\mathrm{C})$, and strong staining of the BBM in the proximal tubule $S 3$ segments, whereas the individual cells (arrows) are strongly stained. At pH $6(D)$, there is a strong staining of BBM, without a significant background. At $\mathrm{pH} 8(E)$, the staining of $B B M$ in the $S 3$ is weak. (F-H) In cryosections pre-treated with alcohols, followed by microwave heating in citrate buffer of $p H 3(F), p H 6(G)$, and $p H 8(H)$, the staining intensity of $B B M$ in the proximal tubule $\mathrm{S} 3$ segments at $\mathrm{pH} 3$ and $\mathrm{pH} 6$ is much weaker than at $\mathrm{pH} 8$, and similar to the staining in the respective microwave-treated cryosections. Scale bar $=20 \mu \mathrm{m}$ 
the kidneys fixed in vivo. In the untreated cryosections, the tubules showed no significant staining (A), whereas in the SDS-treated cryosections, a weak staining of the BBM in PT S3 segments was observed (B). In the microwave-treated cryosections, overall staining intensity in the PT S3 segments was $\mathrm{pH}$ dependent, exhibiting the pattern $\mathrm{pH} 3>\mathrm{pH} 6>\mathrm{pH} 8$ (C, D, and E, respectively). The same pattern was observed for the intensity of non-specific background staining. In addition, at $\mathrm{pH} 3$, individual cells were heavily stained in toto ( $\mathrm{C}$, arrows). In cryosections pretreated with alcohols, followed by microwave heating in citrate buffer, background and BBM staining was much less intense, and exhibited an inverse pattern $(\mathrm{pH} 3<\mathrm{pH} 6<\mathrm{pH} 8)$.

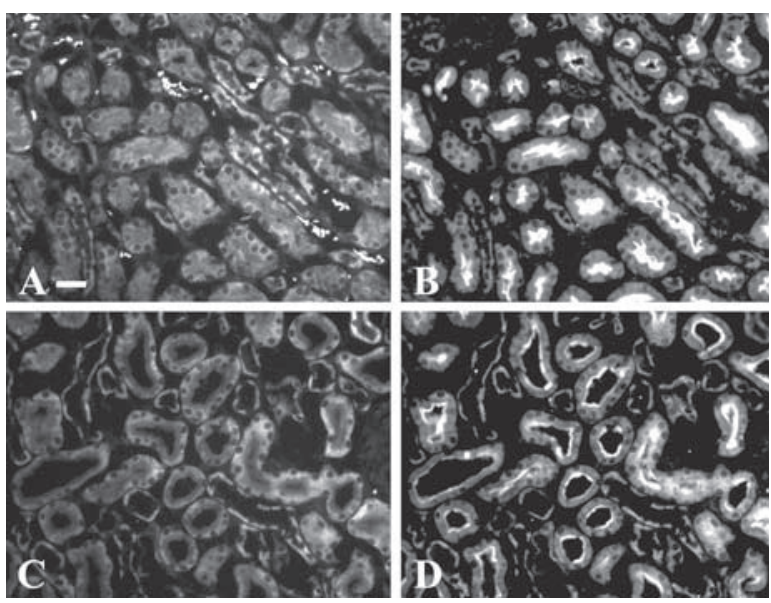

Figure 8 Comparison of proximal tubule $S 3$ segment morphology $(A, C)$ and Oat5 immunostaining $(B$, $D)$ in the same tubules in the outer stripe between cryosections of the kidneys fixed in vitro $(A, B)$ and in vivo $(C, D)$ that were microwave-treated at $\mathrm{pH} 6$. (A) All S3 segments in the kidneys fixed in vitro have collapsed lumina, filled with cellular debris, whereas $(B)$ Oat 5 in the BBM of the same tubules is strongly stained. (C) Proximal tubule S3 segments in cryosections of the kidneys fixed in vivo are open, with sharp borders and regular appearance, and (D) the intensity of Oat5 staining in their BBM is weaker than in cryosections of the kidneys fixed in vivo. Scale bar $=20 \mu \mathrm{m}$

Due to lower background and strong BBM staining in the microwave only-treated sections at $\mathrm{pH} \mathrm{6,} \mathrm{these} \mathrm{conditions} \mathrm{were} \mathrm{chosen} \mathrm{to} \mathrm{compare} \mathrm{the}$ morphology and Oat5 staining in cryosections of the kidneys fixed in vitro and in vivo (Figure 8). The tubules in cryosections of the kidneys fixed in vitro had collapsed lumina, filled with cellular debris (A), whereas the tubules in cryosections of the kidneys fixed in vivo had regular appearance, with open lumina and sharp borders (C). However, the intensity of Oat5 immunostaining in the BBM of PT S3 segments was higher in cryosections of the kidneys fixed in vitro.

\section{DISCUSSION}

Harsh antigen retrieval methods, such as delipidation with alcohols, microwave heating in buffers of different $\mathrm{pH}$, and autoclaving, are usually used to recover cryptic epitopes in sections of formalin-fixed, paraffin-embedded tissues $(1-10,12)$. Such techniques have not regularly been used with cryosections. More is known about the use of SDS in cryosections of the PFA-fixed rat tissues and cultured cells. As shown in previous publications (12-14), SDS effects in cryosections are antigen-dependent; some invisible antigens can be revealed, the immunostaining of some antigens can be enhanced, whereas the staining intensity of others remains unchanged.

In order to define optimal conditions for immunostaining various Oats in cryosections of the PFA-fixed rat kidneys, we applied two stronger methods in this study in addition to SDS, that is, microwave heating and delipidation in alcohols plus microwave heating in citrate buffers of different $\mathrm{pH}$. After applying these experimental conditions on cryosections of rat kidneys fixed in vivo, the data showed the following overall pattern of staining intensity of Oats: untreated $<$ SDS-treated $\leqq$ alcoholtreated $<$ microwave-treated. Specifically, in untreated cryosections all Oats were barely stained, and SDS treatment slightly increased the staining of Oat1, Oat2, and Oat5, but not of Oat3. Alcohol pre-treatment and microwave heating enhanced the staining effect in all tested Oats. These data indicate that Oat epitopes may interact with lipids, and/or are deeply embedded (masked) in the cell membrane matrix, which protects from antibody binding, and are unmasked either by detergent treatment (weakly) or after denaturation by alcohols and/or heating in a microwave (stronger). With these experiments we have proven that the PFA (formalin) fixation masks the epitopes $(1,10)$, and that any kind of antigen retrieval increases their number. However, SDS-treatment could not retrieve many cryptic epitopes, whereas microwave treatment retrieved more, but in a $\mathrm{pH}$ - and antigendependent manner. Staining intensity after heating in a microwave exhibited the following $\mathrm{pH}$-dependency patterns: $\mathrm{pH} 3<\mathrm{pH} 6<\mathrm{pH} 8$ for Oat1, $\mathrm{pH} 3>\mathrm{pH} 6=\mathrm{pH} 8$ for Oat3, and $\mathrm{pH} 3>\mathrm{pH} 6>\mathrm{pH} 8$ for Oat2 and Oat5. Compared to microwave treatment alone, pre- 
treatment of cryosections with alcohols, followed by microwave heating, resulted in weaker staining intensity of all tested Oats, possibly because alcohols damaged the epitopes.

Although our results showed that antigen retrieval for rOat1 was best with microwave heating in citrate buffer of $\mathrm{pH} 8$, this $\mathrm{pH}$ also caused a partial or complete detachment of cryosections from the glass slides. Therefore, it is not favourable for routine work.

We conclude that microwave treatment alone, in citrate buffer of $\mathrm{pH} 6$ best reveals Oat1, Oat2, and Oat 5 epitopes, whereas $\mathrm{pH} 3$ is best for Oat 3 epitopes. With this method and conditions, specific staining was strong, non-specific background staining was weak, and no staining artefacts were observed with the Oatspecific antibodies. At this point, we have to admit that our previous studies of Oat1, performed with SDStreated cryosections, and of Oat3, with cryosections treated with alcohols and microwave heating in a pH 3 citrate buffer (15), were not performed with the optimal revealing methods and conditions, and probably underestimated the expression of antigens along the rat nephron.

As expected, tubules in cryosections from the kidneys fixed in vitro had collapsed lumina full of cell debris, possibly due to a hypoxic damage caused by prolonged fixation time in vitro. Judging by the open lumina and regular morphology, tubules fixed in vivo did not sustain such damage. However, under optimal immunocytochemical conditions, the staining intensity of basolateral transporters Oat1 and Oat 3 was similar between cryosections of kidneys perfused in vitro and in vivo, whereas the staining intensity of brush-border transporters Oat 2 and Oat5 was higher in cryosections of the kidneys fixed in vitro. These data suggest that PFA-fixation by perfusion in vivo is the method of choice for immunostaining basolateral transporters, whereas PFA-fixation in vitro seems to be better for presenting brush-border transporters. The reason for these differences is not clear, but several explanations come to mind: a) during fixation in vivo, the BBM may be overfixed, and the epitopes need a stronger "unmasking" treatment, b) the hypoxic damage of the BBM during slower fixation in vitro may have a kind of "diggestive" effect and expose more epitopes, and c) the well known differences in the fluidity of these two membrane domains, determined by different content of phospholipids and cholesterol (21, and references in there), may be critical for epitope sensitivity to PFA fixation, heating, and $\mathrm{pH}$.

In conclusion, our studies teach us that: a) some harsh antigen retrieval techniques, previously used with sections of formalin-fixed, paraffin-embedded tissues, can be efficiently used with cryosections of the PFA-fixed tissues, and b) specific Oats, and probably other renal transporters in the rat kidney and other mammamalian organs have to be treated individually, with different fixation and antigen retrieval methods in order to define the optimal method and conditions for their immunocytochemical presentation.

\section{Acknowledgements}

The authors wish to thank Mrs Eva Heršak for technical assistance. This work was supported by the Ministry of Science, Education and Sports, Republic of Croatia (grant no. 022-0222148-2146).

\section{REFERENCES}

1. Brown D. Analysis of protein expression by immunocytochemistry. In: Hames BD, Higgins S, editors. Gene probes: a practical approach. Oxford (UK): Oxford University Press; 1995. p. 267-311.

2. McNicol AM, Richmond JA. Optimizing immunohistochemistry: antigen retrieval and signal amplification. Histopathology 1998;32:97-103.

3. Leong AS, Gilham PN. The effects of progressive formaldehyde fixation on the preservation of tissue antigens. Pathology 1989;21:266-8.

4. Shi S-R, Cote RJ, Taylor CR. Antigen Retrieval Techniques: Current Perspectives. J Histochem Cytochem 2001;49:9317.

5. Leong ASY, Lee ES, Yin H, Kear M, Haffajee Z, Pepperall D. Superheating Antigen Retrieval. Appl Immunohistochem Mol Morphol 2002;10:263-8.

6. Hoetelmans RWM, van Slooten HJ, Keijzer R, van de Velde CJH, van Dierendonck JH. Comparison of the effect of microwave heating and high pressure cooking for antigen retrieval of human and rat $\mathrm{Bcl}-2$ protein in formaldehyde fixed paraffin embedded sections. Biotech Histochem 2002;77:137-44.

7. Shi SR, Cote RJ, Chaiwun B, Young LL, Shi Y, Hawes D, Chen TY, Taylor CR. Standardization of immunohistochemistry based on antigen retrieval technique for routine formalin fixed tissue sections. Appl Immunohistochem 1998;6:89-96.

8. Norton AJ, Jordan S, Yeomans P. Brief, high temperature heat denaturation (pressure cooking) a simple and effective method of antigen retrieval for routine processed tissues. J Pathol 1994;173:371-9.

9. Leong ASY, Leong FJWM. Microwave-stimulated antigen retrieval - an update. Acta Histochem Cythochem 2002;35:367-74.

10. Shi SR, Cote RJ, Taylor CR. Antigen retrieval. Immunohistochemistry: past, present and future. J Histochem Cytochem 1997;45:327-43.

11. Grossfeld GD, Shi SR, Ginsberg DA, Rich KA, Skinner DG, Taylor CR, Cote RJ. Immunohistochemical detection of thrombospondin-1 in formalin-fixed, paraffin embedded tissue. J Histochem Cytochem 1996;44:761-7.

12. Brown D, John L, McLaughlin M, Stuart-Tilley A, Tyskowski $\mathrm{R}$, Alper S. Antigen retrieval in cryostat tissue sections and 
cultured cells by treatment with sodium dodecyl sulfate (SDS). Histochem Cell Biol 1996;105:261-7.

13. Alper SL, Stuart-Tilley AK, Biemesderfer D, Shmukler B, Brown D. Immunolocalization of AE2 anion exchanger in rat kidney. Am J Physiol 1997;273:F601-14.

14. Sabolić I, Herak-Kramberger CM, Breton S, Brown D. Na/KATPase in intercalated cells along the rat nephron revealed by antigen retrieval. J Am Soc Nephrol 1999;10:913-22.

15. Ljubojević M, Herak-Kramberger CM, Hagos Y, Bahn A, Endou H, Burckhardt G, Sabolić I. Rat renal cortical OAT1 and OAT3 exhibit gender differences determined by both androgen stimulation and estrogen inhibition. Am J Physiol - Renal Physiol 2004;287:F124-38.

16. Ljubojević M, Balen D, Breljak D, Kušan M, Anzai N, Bahn A, Burckhardt G, Sabolić I. Renal expression of organic anion transporter OAT2 in rats an mice is regulated by sex hormones. Am J Physiol - Renal Physiol 2007;292:F361-72.

17. Tojo A, Sekine T, Makajima N, Hosoyamada M, Kanai Y, Kimura K, Endou H. Immunohistochemical localization of multispecific renal organic anion transporter 1 in rat kidney. J Am Soc Nephrol 1999;10:464-71.

18. Kojima R, Sekine T, Kawachi M, Cha SH, Suzuki Y, Endou H. Immunolocalization of multispecific organic anion transporters, OAT1, OAT2, and OAT3, in the kidney. J Am Soc Nephrol 2002;13:848-57.

19. Cha SH, Sekine T, Fukushima J, Kanai Y, Kobayashi Y, Goya $\mathrm{T}$, Endou H. Identification and characterization of human organic anion transporter 3 expressing predominantly in the kidney. Mol Pharmacol 2001;59:1277-86.

20. Brzica H, Breljak D. Ljubojević M, Balen D, Žlender V, Kušan M, Anzai N, Sabolić I. The expression of organic anion transporter Oat5 in rat kidney is gender dependent. Renal Week 2007 - American Society Nephrology; San Francisco, CA, USA 2007. J Am Soc Nephrol 2007;18:348A.

21. Žuvić-Butorac M, Herak-Kramberger CM, Krilov D, Sabolić I, Herak JN. EPR study of lipid phase in renal cortical membrane organelles from intact and cadmium-intoxicated rats. Biochim Biophys Acta 2005;1718:44-52. 
Sažetak

\section{OPTIMALNE METODE OTKRIVANJA ANTIGENA ZA PRIJENOSNIKE ORGANSKIH ANIONA} U KRIOSTATSKIM NARESCIMA ŠTAKORSKOG BUBREGA

Za imunocitokemijsku (IC) lokalizaciju antigena uzorci tkiva ili stanica obično se denaturiraju fiksacijom, a potom se odmah smrznu i naresci režu kriostatom ili se uklope u parafin prije rezanja narezaka. Parafin se kasnije odstrani alkoholima. p-Formaldehid (PFA; formalin) čest je fiksativ, koji čuva antigeničnost proteina, ali oštećuje morfologiju stanica i "maskira" vezna mjesta za protutijela (epitope). Za "demaskiranje" epitopa potrebno je primijeniti neku od metoda otkrivanja (regeneracije) antigena (RA). Namjera ove studije jest: a) odrediti optimalnu metodu RA u kriostatskim narescima PFA-fiksiranih bubrega in vivo za prijenosnike organskih aniona (Oat) smještene u bazolateralnoj (Oat1, Oat3) i četkastoj (Oat2, Oat5) membrani proksimalnih kanalića u bubrezima štakora i b) rabeći optimalnu metodu, usporediti IC bojenje Oat-a u bubrezima koji su bili PFA-fiksirani in vivo ili in vitro. IC bojenje u neobrađenim kriostatskim narescima uspoređeno je s bojenjem nakon obrade detergentom ili mikrovalnim kuhanjem u citratnom puferu $\mathrm{pH}$ 3, $\mathrm{pH} 6$ ili pH 8, s prethodnom obradom alkoholima ili bez nje. Optimalni RA-uvjet za Oat1, Oat2 i Oat5 bio je kuhanje narezaka pri $\mathrm{pH}$ 6, a za Oat3 pri pH 3, bez prethodne obrade alkoholima. U usporedbi s tkivom fiksiranim in vivo, tkivo fiksirano in vitro imalo je: oštećenu morfologiju kanalića, sličnu jačinu bojenja Oat1 i Oat3, a jače bojenje Oat2 i Oat5. Zaključujemo da svaki Oat u bubregu štakora treba obraditi pojedinačno, s različitom fiksacijom i metodom RA, kako bi se našli optimalni uvjeti za njegovo IC prikazivanje.

KLJUČNE RIJEČI: imunocitokemija, imunofluorescencija, kriostatski naresci, membranski prijenosnici, proksimalni kanalići, stanična membrana

CORRESPONDING AUTHOR:

Ivan Sabolić, M.D., Ph.D.

Unit of Molecular Toxicology

Institute for Medical Research and Occupational Health

Ksaverska cesta 2

HR-10001 Zagreb

E-mail: sabolic@imi.hr 